\title{
Red-Bellied Woodpecker at Regina
}

by Robert W. Nero, Saskatchewan Museum of Natural History
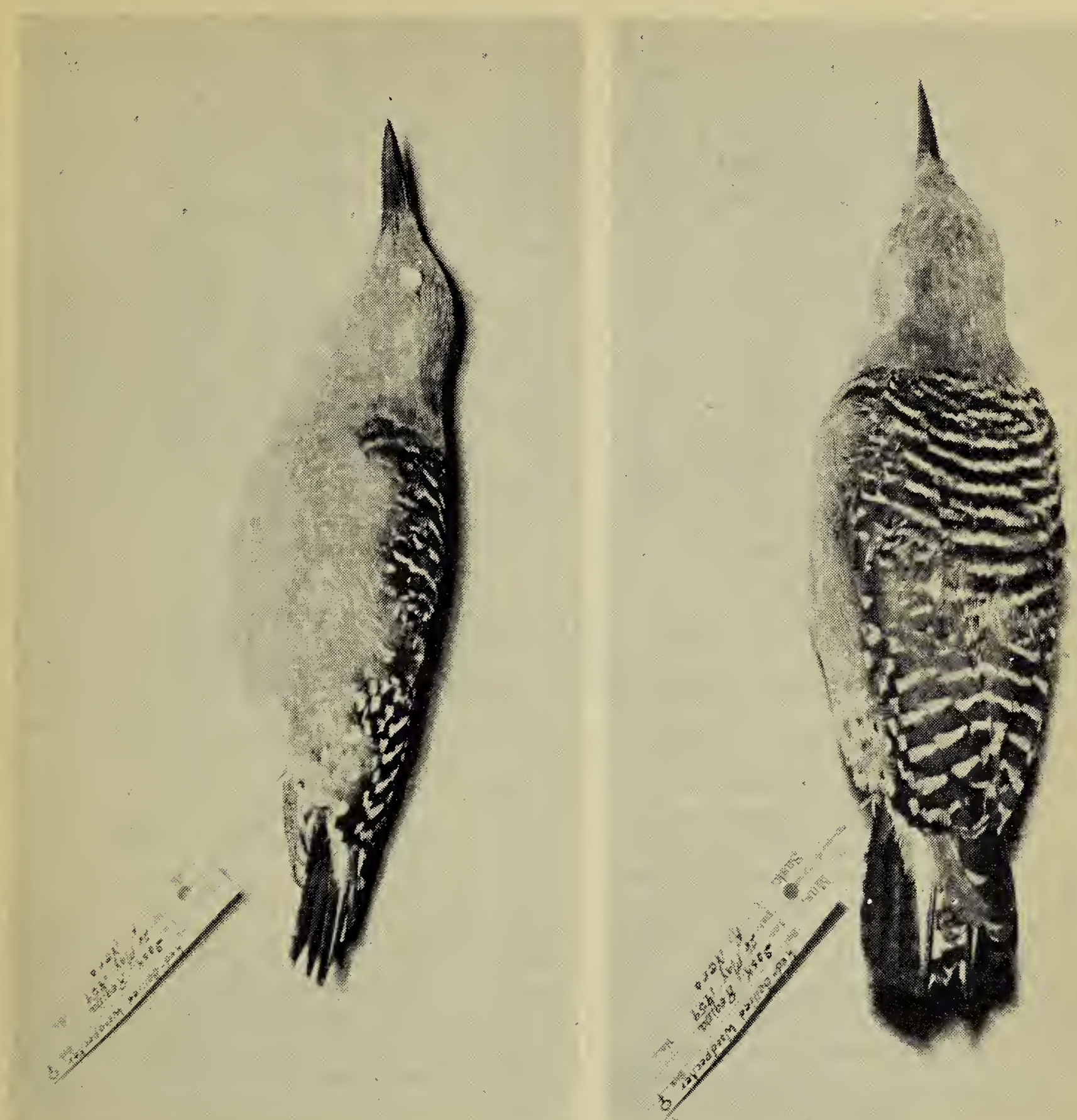

Photo by B. C. Shier

Red-bellied Woodpecker (Centurus carolinus) taken at Regina, May 26, 1959.

On May 23, 1959, George F. Ledingham observed a female Redbellied Woodpecker (Centurus carolinus), a species not previously reported for the province, in the grounds at the Legislative Buildings in Regina. The bird was seen again on May 25 by Frank H. Brazier and Dr. Isabelle Coleman. A number of others tried but failed to see it on that day, but in the early morning of May 26 Ledingham found it again among some small trees on the edge of Lake Wascana. He telephoned me at once and with his co-operation the bird was collected, thus providing a permanent and positive record. The specimen has been prepared as a study skin for the collections of the Saskatchewan Museum of Natural History, where it may be examined. The specimen was an adult female in apparently good health although the rectrices were noticeably abraded. II was moderately fat, had welldeveloped ova (largest ovum - three $\mathrm{mm}$.), and weighed 80 grams. The gizzard contents included fragmentary parts of numerous insects including coleoptera and diptera (adult and sub-adult forms), several very small feathers, several particles of grit (quartz) and surprisingly, five whole fish vertebrae (about two $\mathrm{mm}$. in size) and several bony fragments. The whole mixture had a decidedly 
fishy odor suggesting that the bird had dined on all or part of a minnow. There are a great many dead minnqws along the shores of Wascana Lake at this season.

The Red-bellied Woodpecker is a species of the southeastern United States woodlands, breeding west to Texas and eastern Nebraska and north to southern Minnesota and New York (A.O.U. Check-list, 1957). It occurs "very rarely in extreme southern sections" of Ontario (Snyder, L.L., 1951. Ontario Birds, p.142), and has been reported in Manitoba: a female seen at Brandon (200 miles east of Regina) on January 1, 1956 (Bird, R. D., 1956. Blue Jay, 14:7); a pair at Winnipeg throughout the month of June, 1941; and a male at Sanford in January, 1942 (Cartwright, B. W., 1942. Can. Field-Nat.,
56: 45-46). It is known accidentally in Colorada, South Dakota and North Dakota. A specimen was taken in Nelson County, North Dakota in September, 1897 (Wood, N. A., 1923. A preliminary survey of the bird life of North Dakota. Univ Mich. Mus. Zool., Misc. Pub. No. 10, p. 48). A Red-bellied Woodpecker was seen in South Dakota on May 12, 1958 at Mitchell, (Audubon Field Notes, August, 1958, Vol. 12:364); and during the winter (Dec. 1, 1958-March 31,1959 ) three were seen at Sioux Falls and four along the Big Sioux River near Brookings, South Dakota (Audubon Field Notes, Vol. 13:303). We are indebted to W. Earl Godfrey, Curator of Ornithology, Natural History Branch, National Museum of Canada, for assistance in locating the above records.

\section{A Report on Spring Migration in the Regina Area, 1959}

by Fred W. Lahrman, Saskatchewan Museum of Natural History

Last year members of the Museum staff and of the bird group of the Regina Natural History Society submitted records of the spring migration in the Regina area to the Museum where I kept a list of first arrival dates. Records submitted up to April 30, 1958 were published in the Blue Jay (Vol. XVI, 59). A similar co-operative study was made this year. Using the records of many interested field observers in the Regina area, the following list of first arrival dates has been prepared. The list includes records submitted up to June 1, 1959 when Ralph Ostoforoff and I saw two flocks (ca. 12 and ca. 30) of Buff-breasted Sandpipers in a dry field 10 miles east of the city.

\section{FIRST ARRIVAL DATES, SPRING 1959}

Date Species

April 20 Horned Grebe (1)

April 29 Eared Grebe (2)

May 1 Western Grebe (1)

April 18 Pied-billed Grebe (1)

April 25 Double-crested Cormorant (1)

April 11 Great Blue Heron (2)

May 8 American Bittern (1)

March 31 Whistling Swan (9)

March 22 Canada Goose (2)

March 27 White-fronted Goose (small flock)
Date

Species

March 27 Snow Goose (1)

April 11 Blue Goose

March 21 Mallard

April 3 Gadwall (3)

March 22 Pintail (20 plus)

April 1 Green-winged Teal (2)

April 18 Blue-winged Teal (1)

March 21 American Widgeon (2)

March 22 Shoveler (1)

April 2 Redhead (12)

April 1 Ring-necked Duck (3)

April 6 Canvasback (10 plus)

April 6 Lesser Scaup (several)

March 24 Common Goldeneye

April 6 Bufflehead (2)

April 26 Ruddy Duck (2)

March 22 Common Merganser (3)

April 6 Red-breasted Merganser

April 29 Sharp-shinned Hawk (1)

March 21 Red-tailed Hawk (2)

May 3 Broad-winged Hawk (1)

April 25 Swainson's Hawk (2)

March 21 Rough-legged Hawk (1)

March 11 Bald Eagle (1)

March 22 Pigeon Hawk (1)

April 9 Sparrow Hawk (1)

April 9 Sandhill Crane (flock)

April 16 American Coot (2)

April 27 Semipalmated Plover (4)

May 19 Piping Plover (1)

March 26 Killdeer

May 5 American Golden Plover (flock)

May 18 Black-bellied. Plover (2) 